\title{
Altruistic Individualists: Motivations for International Volunteering Among Young Adults in Switzerland
}

\author{
Walter Rehberg ${ }^{1,2}$
}

\begin{abstract}
Modernization theory posits a change from traditional or "collective" forms to modern or "reflective" forms of volunteering. In a research project using a combined qualitative-quantitative approach, the motivation of 118 young Swiss adults who showed an interest in international volunteering was investigated. Qualitative analysis revealed 12 different motives which could be categorized into three different groups: A first group called "Achieving something positive for others," a second group named "Quest for the new," and a third group of motives labeled "Quest for oneself." Motivations of young Swiss adults for international volunteering clearly show the characteristics of "reflexive" volunteers. Most respondents displayed a combination of motives while for only $11 \%$ of them altruism ("Achieving something positive for others") was the one and only driving force behind their interest in international volunteering. The inductively constructed typology of motives can be a useful planning device for organizations that run or intend to set up an international volunteering program for young adults.
\end{abstract}

KEY WORDS: international volunteering; young adults; motivation; Switzerland.

\section{INTRODUCTION}

There is a broad consensus among students of volunteerism that it is undergoing a structural change from "old," "classical," or "traditional" to "new" or "modern" volunteering (Jakob, 1993; Brandenburg, 1995; Boessenecker, 1999; Heinze and Olk, 1999). "Old" volunteering is closely connected to certain social milieus such as religious or political communities, involves a long-term and often

\footnotetext{
${ }^{1}$ Berne University of Applied Sciences, School of Social Work, Berne, Switzerland

${ }^{2}$ Correspondence should be directed to Walter Rehberg, Falkenplatz 24, Postfach 6564, CH-3001 Bern, Switzerland; e-mail: walter.rehberg@hsa.bfh.ch
} 
membership-based commitment, and for which altruistic motivations play a key role for the involvement of individuals. "New" volunteering on the other hand is more project oriented, and volunteers have specific expectations as to form, time, and content of their involvement. Hustinx (2001) has found evidence for "new" volunteering among young participants in international work camps: young volunteers are not particularly loyal to organizations, tend to be rather choosy about what they do, and expect some personal benefit from their volunteering. Hustinx and Lammertyn (2003) have argued that social transformations fundamentally affect the social bases of volunteer action, and more specifically the biographical frame of reference for volunteers. Theories of a "second," "late," or "reflexive" modernization (Beck and Beck-Gernsheim, 1996; Beck, 1997; 2003) propose the emergence of self-reflexive biographical forms which at the same time increase individual freedom of choice and place the individuals in uncertain and risky situations. Such self-reflexive biographical forms coexist and have, to a certain extent, replaced more collective biographical forms that tend to involve more stable and taken-for-granted life trajectories. In Hustinx and Lammertyn's (2003) view, the accounts of "traditional" and "modern" forms of volunteering reflect the fact that contemporary individuals oscillate between collective and reflexive biographical sources of determination.

Motives for "collective" volunteer efforts are rooted in a communal orientation with a strong sense of duty to a local community (Hustinx and Lammertyn, 2003). These motives frequently stem from a religious tradition of altruism or are inspired by coordinating ideology or meaning systems. Through devoted community service, the "collective" volunteer achieves biographical stability and is relieved from reflexive autonomous identity and biography construction. For the "reflexive" volunteer, motivation for volunteering arises from experiences of biographical discontinuity caused by life crises or self-chosen biographical reorientation. A pluralization of motives occurs among reflexive volunteers who combine self-directed or instrumental motives with a sense of compassion or duty. A form of "altruistic individualism" (Beck, 1997) is characteristic of the motivational basis of the reflective volunteer.

Previous empirical studies have focused on the motivations of hospital volunteers (Zweigenhaft et al., 1996), AIDS volunteers (Murrant and Strathdee, 1995; Omoto and Snyder, 1995; Reeder et al., 2001), or older volunteers in general (Okun et al., 1998; Pushkar et al., 2001). Investigations into the motivation underlying young adults' volunteering have concentrated primarily on university students' motives to get involved in domestic voluntary efforts (Switzer et al., 1999; Fletcher and Major, 2004). To date—perhaps with the exception of Hustinx's (2001) study of participants in international work camps-an empirical investigation of the motivations of young adults, who intend to volunteer internationally, has not been carried out.

Earlier quantitative studies on the motivation of volunteers have used predefined categories of motives in closed-ended questions to survey the frequency 
of such motives in various populations. Some of these studies derived their categories from theoretical systems such as functional theories on beliefs and behaviors (Clary et al., 1996). The downside of these research designs - at least viewed from a more qualitative methodological perspective - is that important information may definitely be missed, since the informants can do nothing but choose between categories set up in advance by the researchers. On the other hand, earlier qualitative studies on volunteer motivation (Chambré, 1995; Brooks, 2002; Yeung, 2004) have developed intriguing typologies of motives and new theoretical insights from a relatively small sample of strategically or conveniently chosen informants. Yeung (2004), for example, used text data from conversations with 18 church volunteers to construct a model of volunteer motivation within a phenomenological framework. Despite their undoubted heuristic merits, such studies tend to suffer from their rather limited number of cases and the associated problems of generalizing the results: How were the resulting typologies and theoretical models influenced by randomly chosen cases? Would a different typology or model have resulted from differently chosen cases?

In light of these theoretical and methodological considerations, the research project on which the present paper is based sought to achieve the following two aims. First, information on the motivation of young adults interested in international volunteering would be collected systematically with a combined qualitativequantitative research design such that the resulting inductively constructed typology should be a useful planning device for organizations that currently run or intend to start a program for young adults in international volunteering. Second, the results are interpreted within the framework of modernization theory.

\section{RESEARCH METHOD}

Between February and May 2003 a total of 404 young adults were contacted via the humanitarian aid organization Caritas Switzerland or the "Center for Information, Advice, and Training (Cinfo)," an organization jointly run by Swiss institutions which are active in international cooperation. All potential informants had approached Caritas or Cinfo during the previous year to inquire about options in international volunteering. The young adults received a postcard or an e-mail with a request for an interview. A total of 118 interviews were conducted by trained interviewers, which represents a response rate of $29 \%$. Forty-two respondents were recruited via Caritas Switzerland, and the remaining 76 interviewees via Cinfo. One hundred and eight interviews were conducted by telephone, and an additional 10 interviewees received and returned the questionnaire by e-mail, since they could not be reached by phone. Thirty-five interviews (30\%) were conducted in French, and 83 (70\%) in German.

Semi-structured telephone interviews promised to effectuate the best results for the research problem to be tackled. In contrast to personal interviews or focus 
groups, expenses for reaching the study participants who lived scattered all over Switzerland could be kept low; the central questions concerning motivation for international volunteering could be much better investigated in telephone interviews than by written postal surveys; and investigating motivations and expectations with closed-ended questions would not have lead to potentially new and interesting insights. Semi-structured telephone interviews were used in previous studies on volunteering by Bachmann and Bieri (2000), and by Barlow and Hainsworth (2001).

The semi-structured questionnaire contained closed-format questions on sociodemographic characteristics of the informants (age, sex, nationality, educational level, and work experience), their religious affiliation, and personal experiences as well as experiences of friends and relatives in national or international volunteering. Questions on religious affiliation were added, since altruism based on religious or other belief systems was the most important motivator for "collective" volunteering. For the question on motivation for volunteering, an open format was used and, with the permission of the interviewees, the answers were recorded and subsequently transcribed verbatim. The question on motives was worded as follows: "Why are you interested in volunteering in the field of international cooperation?"

Interviewers were instructed to first listen to the answers and then ask for further details or clarifications as appropriate. From the qualitative text data on motivations, categories were constructed and the texts coded accordingly. The coding procedure was repeated twice and the code list consequently revised to assure maximum validity of all codes. In what follows, the typology of motives are presented and discussed.

\section{RESEARCH RESULTS}

Of the 118 respondents, $64 \%$ were female and $36 \%$ male, their average age was 24 years, and $91 \%$ were Swiss nationals. Ten percent had completed compulsory education, $31 \%$ vocational training, $41 \%$ high school education, and $18 \%$ had received a university or other post-secondary degree. Some $57 \%$ were enrolled in some kind of training or professional education, and $67 \%$ worked at least part-time. It was found that $69 \%$ of the young adults had previous experience in volunteering, $24 \%$ had previously volunteered internationally, and $10 \%$ were active members of churches or religious communities. Fifty-five percent of the respondents had a relative or a friend who volunteers on a regular basis and 52\% knew somebody personally who had experience in international volunteering or international cooperation.

The motives of respondents for international volunteering were classified into 12 categories that in turn were subsumed in 3 groups of motivations. Table I depicts the frequency of the motives and groups of motivations. The three groups 
Table I. Motives of Young Adults for International Volunteering

\begin{tabular}{|c|c|c|}
\hline \multirow[b]{2}{*}{ Motivation of respondents } & \multicolumn{2}{|c|}{$\begin{array}{l}\text { Interviews where motive was mentioned } \\
(n=118 ; \text { multiple responses possible })\end{array}$} \\
\hline & Frequency & $\begin{array}{c}\text { Proportion of } \\
\text { all interviews }(\%)\end{array}$ \\
\hline $\begin{array}{l}\text { Group } 1 \text { "Achieving something positive } \\
\text { for others" }\end{array}$ & 91 & 77 \\
\hline Motive 1.1 "Helping, giving, doing good" & 56 & 48 \\
\hline $\begin{array}{l}\text { Motive } 1.2 \text { "Achieving or changing } \\
\text { something" }\end{array}$ & 44 & 37 \\
\hline $\begin{array}{l}\text { Motive } 1.3 \text { "Being geared to ethical } \\
\text { values" }\end{array}$ & 22 & 19 \\
\hline $\begin{array}{l}\text { Motive } 1.4 \text { "Feeling useful, doing } \\
\text { something useful" }\end{array}$ & 10 & 9 \\
\hline Group 2 "Quest for the new" & 88 & 75 \\
\hline $\begin{array}{l}\text { Motive } 2.1 \text { "Becoming acquainted with } \\
\text { new cultures, intercultural exchange" }\end{array}$ & 55 & 47 \\
\hline $\begin{array}{l}\text { Motive } 2.2 \text { "Doing something different, } \\
\text { getting away" }\end{array}$ & 36 & 31 \\
\hline $\begin{array}{l}\text { Motive } 2.3 \text { "Getting deeply acquainted } \\
\text { with a new culture and everyday life" }\end{array}$ & 29 & 25 \\
\hline $\begin{array}{l}\text { Motive } 2.4 \text { "Meeting new people, making } \\
\text { new friends" }\end{array}$ & 19 & 16 \\
\hline $\begin{array}{l}\text { Motive } 2.5 \text { "Learning or using foreign } \\
\text { languages" }\end{array}$ & 18 & 15 \\
\hline Group 3 "Quest for oneself" & 79 & 67 \\
\hline $\begin{array}{l}\text { Motive } 3.1 \text { "Gaining experience, } \\
\text { advancing oneself" }\end{array}$ & 60 & 51 \\
\hline $\begin{array}{l}\text { Motive } 3.2 \text { "Professional orientation, } \\
\text { clarification, and development" }\end{array}$ & 31 & 26 \\
\hline $\begin{array}{l}\text { Motive } 3.3 \text { "Discovering or transcending } \\
\text { personal limits" }\end{array}$ & 13 & 11 \\
\hline
\end{tabular}

of motivations occurred with a similar frequency: $77 \%$ of the respondents were motivated by "Achieving something positive for others," $75 \%$ were motivated by a "Quest for the new," and 67\% were on a "Quest for oneself." The most common single motives were "Gaining experience, advancing oneself" (51\%), "Helping, giving something, doing good" (48\%), "Becoming acquainted with new cultures, intercultural exchange" (47\%), "Achieving or changing something" (37\%), "Doing something different, getting away from here" (31\%), and "Professional orientation, clarification, and development" (26\%). No statistically significant differences concerning the importance of these motives were found between men and women or between older and younger respondents. For respondents with previous experience in international volunteering or international cooperation, the motive "Doing something different, getting away from here" was significantly less important than for young adults without such an experience; for all other motives, experienced and non-experienced respondents did not differ in their motivation for international volunteering. 
Table II. Simultaneous Occurrence of Motives

\begin{tabular}{lcc}
\hline \multicolumn{1}{c}{ Motivation of respondents } & Frequency & $\begin{array}{c}\text { Proportion of } \\
\text { all interviews (\%) }\end{array}$ \\
\hline $\begin{array}{l}\text { Only group 1 "Achieving something positive } \\
\text { for others" }\end{array}$ & 13 & 11 \\
Only group 2 "Quest for the new" & 8 & 7 \\
Only group 3 "Quest for oneself" & 4 & 3 \\
Groups 1 and 2 combined & 18 & 15 \\
Groups 1 and 3 combined & 13 & 11 \\
Groups 2 and 3 combined & 15 & 13 \\
Groups 1, 2, and 3 combined & 47 & 40 \\
Total & 118 & 100 \\
\hline
\end{tabular}

Typically, a single motive did not occur alone, but in combination with a motive from another group. As can be seen in Table II, only $21 \%$ of the respondents mentioned a motive (or motives) from a single group of motivations, while $39 \%$ of the interviewees were driven by motives from two groups of motivations, and $40 \%$ by a combination from all three groups of motivations. A good illustration of such a combination of motives is the following quotation of a 24-year-old male car mechanic:

\footnotetext{
My motivation is that you can do something which is of help to somebody, that you can achieve something. In such a voluntary program one really gets to know the people, the culture and the living conditions, and that shows you how well off we are in Switzerland. The culture is also very interesting, of course, as is the group of volunteers. You get to know new people, you also learn something about yourself and to value yourself more, because it certainly can be very stressful. (Interview 84)
}

This young man was striving to achieve something which is helpful to others (Motivation Group 1); he really wanted to get to know people, their culture, and living conditions (Motivation Group 2); in addition, he wanted to get to know and value himself more (Motivation Group 3).

In the following sections, the motives for international volunteering-as shown in Table I-will be illustrated by more original quotations from the interviews, which have been translated from German or French. Wherever possible, their original colloquial wording has been left unchanged.

\section{Group 1: "Achieving Something Positive for Others"}

\section{Motive 1.1 "Helping, Giving, Doing Good"}

About one-third $(36 \%)$ of the respondents explicitly used the words "help" or "helping" when talking about their motivation for international volunteering:

Very early in my life I realized that I wanted to help other people, I like to listen to others, and I feel interested in their problems. (Interview 26) 
Especially the help that you can offer the people, the consolation, the strengthening, primarily, and also the exchange between people from different cultures, I am very much interested in that, people with completely different lifestyles. (Interview 119)

Quite frequently, the realization of the "altruistic" motive of helping others was combined with expectations for their own good. By helping others many respondents wanted to achieve an advantage for themselves:

Why do I want to help other people who are not as well off as we are in Switzerland, or most Europeans? I expect inner self-satisfaction, to put it in plain German. (Interview 32)

If I help, I'm also enriching myself because I can see what I've achieved during the day, and in the end I see, I was able to help, I was able to give joy to others. (Interview 46)

That gives me an inner satisfaction. Personally, I'm not so geared towards luxury, it's fulfilling when I see that I can help somebody. (Interview 82)

\section{Motive 1.2 "Achieving or Changing Something”}

The intention to create something and to see and feel the effects of one's own actions lies at the heart of this motive:

Yes, my main motivation is knowing that you can have an effect and that you can be of help, that I can do something, where I can see a result maybe. Well, maybe I see ... yes, I've constructed that well or something like that. Simply the motivation, knowing that those people are better off after such a stay. (Interview 36)

Local political activity in Switzerland isn't always very specific, things don't improve very fast. We discuss things a lot. There are many small steps which can be pretty good, but in general it's rather gooey compared to what I'd like to do personally: to get things moving, to accomplish projects. In this context I also want to see and to experience really concrete things, simple things also, for example in a village, a simple water pump, which can change the life of 50 people in the village quite dramatically. (Interview 60)

Although helping to change or improve the world was an important motive for many informants, in general they showed a very pragmatic and low-key attitude towards helping others. Quite a few of the young adults seem to have the feeling that they have to justify their motive to improve the world with contorted language:

Yeah, I somehow have the need just a little, or I see Switzerland quite a bit like an island, also like a paradise. Yeah, I somehow have the feeling, I don't know, maybe this sounds a little stupid, that somehow also, for me it would be good if I knew, if I could do something for other people who don't have everything. Yeah, maybe it sounds a little bit stupid, but I really do think that somehow. (Interview 49)

\section{Motive 1.3 "Being Geared to Ethical Values"}

Respondents who described their motivation with explicit reference to relatively abstract ethical values predominantly mentioned justice, equality, conscience, 
or responsibility as their guiding principles:

I'm relatively active politically, and I've got a certain social conscience, and therefore for me it was pretty clear that in the future I want to work in the area of social services. (Interview 51)

In these organizations where I'm active for human rights, I think if I don't do it, if we don't do it, who else should do it? I also think it is somehow our obligation, as intelligent human beings, if you recognize injustices and don't do anything about it that is really the worst. (Interview 69)

\section{Motive 1.4 "Feeling Useful, Doing Something Useful"}

The need for a useful or meaningful activity is closely connected with the desire to help, to give, or to do something good (Motive 1). A task is perceived to be use useful if it has the potential to help somebody directly. Professional work in a large organization such as a bank is therefore not considered to be a useful or meaningful activity:

The first point is to do something useful. It somehow started that simply certain jobs I had, I've worked in a bank, and I simply never could identify with that. (Interview 28)

\section{Group 2: "Quest for the New"}

\section{Motive 2.1 "Becoming Acquainted with New Cultures, Intercultural Exchange"}

Getting to know a new culture by the respondents was not seen as an aim in itself, but rather as a means to achieve better understanding or more tolerance between peoples and thus to realize a universal ethical principle:

Culture is very important for me, and getting to know other cultures. I've realized that many problems stem from misunderstandings between cultures. It's my wish to develop a greater tolerance between peoples. I also want to refine my understanding for people. I've also realized that the way somebody acts only makes sense if I know his or her culture better. (Interview 12)

One can also seek contact with a new culture to gain insights into one's own cultural background. In this case, intercultural exchange was also a means to a specific end:

I learn a lot by doing it, it's always intercultural exchange, I always learn a lot about how other people think about that, how do they do it, what their view is on life. By getting closer to them or their culture something really great happens, and that is that I get closer to my own culture and I know myself better, I can explain certain things, why I do things in a certain way, that's really nice. So, getting closer to a foreign culture helps me to get to know my own culture more closely. (Interview 69) 
Not only can becoming acquainted with a foreign culture be used to realize the ethical principle of international understanding but also to learn something new about oneself, thus gaining new perspectives for everyday life in Switzerland:

Learning something about another country, discovering a new culture ... maybe it's a little selfish to put it this way, but ... It's important to be able to use something from this experience for myself, to be able to learn new things about life. Maybe I'll want to change my habits afterwards in Switzerland. (Interview 68)

\section{Motive 2.2 "Doing Something Different, Getting Away from Here"}

Quite frequently, the opportunity to do something completely new in international volunteering went along with a professional reorientation or a general dissatisfaction with working in Switzerland:

First of all, it's for me like a new experience. I've just completed a commercial apprenticeship, to do something completely different, to do something social, because I'd like to work in this field, and I have the feeling that I can find out if that is something for me or not. (Interview 35)

To do something useful, not in this system, with the kind of working practices we have here in Switzerland, but to work in a more project-oriented way, more freely. In this respect getting away from the Swiss system is also an aspect here. (Interview 89)

\section{Motive 2.3 "Getting More Deeply Acquainted with a New Culture and Everyday Life"}

Unlike a long journey, international volunteering offers young people the opportunity to participate in the everyday life of a foreign country. Many respondents offered this explanation for their interest in international volunteering when asked by the interviewer why they did not simply embark on a long journey:

Question: Why are you interested in volunteering and not just travelling?

Answer: I've already done that. I just thought that by helping you get into much closer contact with the people living there. You get a much better grasp of the country, of the people, and you get an impression what the world is like in other places. I consider that to be much more instructive. (Interview 11)

The motive to get more deeply acquainted with everyday life is closely linked to the high expectations respondents have of the organization of a program in international volunteering:

I consider it important that the local population really becomes part of the project because it's also an important goal to get a better feeling for the life and living conditions of the local population. (Interview 87) 


\section{Motive 2.4 "Meeting New People, Making New Friends"}

New people can either be met amongst the locals or within the group of volunteer participants. Being confronted with new people was not only considered as enriching and inspiring but also as potentially strenuous and exhausting:

The culture is also very interesting, but the group of volunteers is too. You get to know new people, but you also learn something about yourself and value yourself more because it can be very strenuous. (Interview 84 )

\section{Motive 2.5 "Learning or Using Foreign Languages"}

Learning or using a foreign language was usually mentioned as a by-product of immersion in a foreign culture:

A positive by-product if you will is that you learn something directly about the culture, that you increase your mastery of the language. These are all positive aspects. (Interview 72)

\section{Group 3: “Quest for Oneself”}

\section{Motive 3.1 "Gaining Experience, Advancing Oneself”}

I want to have experiences abroad since I'm convinced that under such difficult circumstances we can and must develop different skills which we couldn't develop here. (Interview 23)

Expectations about personal development through international volunteering were sometimes quite high: respondents expected to become more mature and self-confident as well as getting more satisfaction from life.

I have a feeling ... I know very well that if I don't do it, I'll regret it. I'll also partly ... it's like becoming mature, and it gives you satisfaction. (Interview 44)

I hope that from international volunteering I'll gain new experiences, and maybe selfconfidence and independence. (Interview 108)

Looking for personal experiences was quite frequently combined with a need for professional orientation:

I intend to head in this direction professionally, and I have the feeling I could gain a lot through such a stay. And afterwards, when I come back and continue working, or if I look for a profession, simply a personal experience. (Interview 35)

\section{Motive 3.2 "Professional Orientation, Clarification, and Development"}

Since some of the young adults were considering a professional career in international cooperation, they wanted to gain experience in this area:

I intend to head in this direction [international cooperation] professionally, and experience in such a voluntary program is usually required. And I also want to find out if I like it, if I 
can work under stressful conditions, because I haven't got any idea really of what it's like to work in that field. (Interview 87)

Younger respondents who were still studying or in vocational education did not usually have such clear-cut plans for their professional future in international cooperation. For them, it was more important to use international volunteering as a vehicle for clarification of their general professional perspectives:

Right now I'm somewhat disoriented in my job, what I want to do in the future, where I'm heading professionally, and maybe such a program can clarify or open perspectives. (Interview 53)

\section{Motive 3.3 "Discovering or Transcending Personal Limits"}

Challenging oneself and thereby getting to know one's own limits is an important means to identity building, particularly for adolescents and young adults:

My personal motivation is rather ... I really like going abroad. Foreign countries for me are a tremendous challenge to my personal development. (Interview 88)

\section{SUMMARY AND DISCUSSION}

As has been argued, motivations of young Swiss adults for international volunteering can be divided into 3 groups containing 12 different motives. A first group of motivations was summarized as "Achieving something positive for others." Volunteers with these motivations want to help or give, to change something. They are explicitly oriented towards ethical values, or they want to feel useful or do something useful. A second category of motivations was described as "Quest for the new." Respondents with these motives want to explore new cultures and meet new people or do something completely different. In addition, they want to learn new foreign languages or use those they already know. A third cluster of motivations is strongly oriented towards the respondents themselves and was therefore summarized as "Quest for oneself." Respondents with a primary motive in this group want to gain personal experience, clarify their professional perspectives, or feel and exceed their personal limits.

Overall, motivations of young Swiss adults for international volunteering clearly show the characteristics of "reflexive" volunteers. Only $10 \%$ of our respondents were active members of a church or a religious community, while altruism based in religious or other belief systems was the most important motivator for "collective" volunteering. As the concept of reflexive volunteering would predict (Hustinx and Lammertyn, 2003), for most of the young adults, a combination of motives was relevant for their interest in international volunteering. For only $11 \%$ of them, altruism ("Achieving something positive for others") was the only driving force behind their interest in international volunteering. With our respondents being "altruistic individualists," altruistic motives typically occurred 
together with more self-centered motives, such as the "Quest for the new" or the "Quest for oneself." Nevertheless, only $23 \%$ of the young adults were solely driven by more self-directed or instrumental motives for volunteering, while for $77 \%$ more altruistic motives were central or at least equally important. This is also in line with findings from other studies that described volunteer motives as an altruism-egoism mixture (Hustinx, 2001; Brooks, 2002; Yeung, 2004).

Volunteering has been theorized to be one of the cornerstones of the social capital of societies: adolescents who volunteer show stronger pro-social attitudes than youths who do not volunteer (Meyer and Budowski, 1993; Wilson, 2000). Through shared voluntary activities individuals learn to know and trust each other. On the other hand, the probability of volunteering is increased by social capital: extensive social networks and multiple memberships in organizations increase the likelihood that individuals volunteer because they might more easily have access to information on volunteering or they might be approached and asked to volunteer. Family and friendship networks are of special importance to induce individuals into volunteering through positive network norms towards volunteering and through the diffusion of knowledge of and experience with volunteering (Janoski et al., 1998; Wilson, 2000).

In our study, there was evidence that many of these mechanisms are also important for international volunteering of young adults: more than half of our respondents had a relative or a friend who had had experience in international volunteering or international cooperation. Although there were no data available on the proportion of the Swiss population with expertise in those fields, it seems safe to assume that the social networks of our respondents exhibited a much higher number of "international experts" than would be expected. Our respondents also had a personal history with a much higher frequency of volunteering than members of the same age group in the Swiss population in general: some 69\% of the young adults interviewed for this study had previous experience in volunteering, while only $37 \%$ of the Swiss population in the same age group are active volunteers (Bundesamt für Statistik, 2001). At least for our respondents it can be said that volunteering leads to more volunteering.

Although there are a wide range of organizations offering educational or work-oriented international programs for youths and young adults, the demand for such programs is much higher than the current supply (Abril and Beck, 2001). Many young adults consider volunteering in an international context a source of valuable experience and, at the same time, an opportunity to put into practice their altruistic philosophy. Therefore, it is not a problem for organizations intending to set up such programs to attract motivated participants.

Such organizations should, however, keep in mind the consequences of the motivations of potential volunteers for program planning. First, the importance of Motive Group 1 "Achieving something positive for others," demands that the program be meaningful and makes a real contribution to solving a problem. Participants would not feel useful (Motive 1.4) or be convinced that they could achieve 
something (Motive 1.2) if the program has no apparent goals and is not suitably structured to reach these goals. Second, Motive Group 2 "Quest for the new" requires the program to be organized in direct contact and cooperation with the local population. It would be difficult for program participants to get deeply acquainted with a new culture and everyday life (Motive 2.3) if participants had to fulfill program tasks that would not allow them to come into contact with the local population. Third, if a "Quest for oneself" (Motive Group 3) is to be successful, this quest needs to be guided by professionally preparing future volunteers, by providing for a seasoned contact person who is available for participants during their assignment in case of difficulties, and by assuring adequate follow-up options to help them reflect on their sometime troublesome intercultural experiences upon returning home. Without such organizational safeguards, gaining experience (Motive 3.1) or discovering and transcending personal limits might turn out to be a stressful and even hazardous adventure.

\section{ACKNOWLEDGMENTS}

The research on which this paper is based was co-financed by the Swiss National Science Foundation (Grant no. 13DO-16030) and Caritas Switzerland. The author is indebted to the project team members Klaus Kühne, Anita Neuenschwander, Sandrine Pétremand, Markus Regner, and Barbara Schweizer from the School of Social Work, Berne University of Applied Sciences, and to Odilo Noti and Josef D'Inca from Caritas Switzerland. The author also wants to thank Klaus Kühne, Harald Klingemann, and anonymous reviewers for their helpful comments on earlier versions of this paper.

\section{REFERENCES}

Abril, C., and Beck, F. (2001). Vernetzte Freiwilligendienste'-Freiwilligendienste in Kooperation von Caritasverband, Pfarrgemeinden und Schulen. In: E. Baldas, H. Schwalb, and W. Tzscheetzsch (eds.), Freiwilligentätigkeit gestaltet Europa. Kooperation in Theorie und Praxis, Lambertus, Freiburg/Breisgau, pp. 227-229.

Bachmann, R., and Bieri, O. (2000). Neue Freiwillige finden. Diskussionspapier 8, Caritas Verlag, Luzern.

Barlow, J., and Hainsworth, J. (2001). Volunteerism among older people with arthritis. Aging and Society 21, 203-217.

Beck, U., and Beck-Gernsheim, E. (1996). Individualization and 'precarious freedoms': Perspectives and controversies of a subject-oriented sociology. In: P. Helaas, S. Lash, and P. Morris (eds.), Detraditionalization, Blackwell, Oxford, pp. 23-48.

Beck, U. (1997). Kinder der Freiheit: Wider das Lamento über den Werteverfall. In: U. Beck (ed.), Kinder der Freiheit, Suhrkamp, Frankfurt/Main, pp. 9-33.

Beck, U. (2003). Risikogesellschaft. Auf dem Weg in eine andere Moderne, Suhrkamp, Frankfurt/Main.

Boessenecker, K.-H. (1999). Ehrenamt und Wohlfahrtsverbände. Soziale Arbeit 48, 87-93.

Brandenburg, H. (1995). Neues Ehrenamt-Herausforderung und Perspektiven. Archiv für Wissenschaft und Praxis der sozialen Arbeit 26, 107-119.

Brooks, K. (2002). Talking about volunteering: A discourse analysis approach to volunteer motivations. Voluntary Action 4(3), 13-50. 
Bundesamt für Statistik (2001). Freiwilligenarbeit in der Schweiz. Neuchâtel.

Chambré, S. M. (1995). Being needful: Family, love, and prayer among AIDS volunteers. Research in the Sociology of Health Care 12, 113-139.

Clary, E. G., Snyder, M., and Stukas, A. A. (1996). Volunteers' motivations: Findings from a national survey. Nonprofit and Voluntary Sector Quarterly 25(4), 485-505.

Fletcher, T. D., and Major, D. A. (2004). Medical students' motivations to volunteer: An examination of the nature of gender differences. Sex Roles 51(1-2), 109-114.

Heinze, R. G., and Olk, T. (1999). Vom Ehrenamt zum bürgerschaftlichen Engagement. Trends des begrifflichen und gesellschaftlichen Strukturwandels. In: E. Kistler, H.-H. Noll, and E. Priller (eds.), Perspektiven gesellschaftlichen Zusammenhalts. Empirische Befunde, Praxiserfahrungen, Messkonzepte, Edition Sigma, Berlin, pp. 77-100.

Hustinx, L. (2001). Individualism and new styles of youth volunteering: An empirical exploration. Voluntary Action 3(2), 47-55.

Hustinx, L., and Lammertyn, F. (2003). Collective and reflexive styles of volunteering: A sociological modernization perspective. Voluntas 14(2), 167-187.

Jakob, G. (1993). Zwischen Dienst und Selbstbezug, Leske und Budrich, Opladen.

Janoski, T., Musick, M., and Wilson, J. (1998). Being volunteered? The impact of social participation and pro-social attitudes on volunteering. Sociological Forum 13, 495-519.

Meyer, P. C., and Budowski, M. (1993). Bezahlte Laienhilfe und freiwillige Nachbarschaftshilfe, Seismo, Zürich.

Murrant, G., and Strathdee, S. A. (1995). Motivations for service volunteer involvement at Casey House AIDS Hospice. Hospice Journal 10(3), 27-38.

Okun, M. A., Barr, A., and Herzog, A. R. (1998). Motivation to volunteer by older adults: A test of competing measurement models. Psychology and Aging 13(4), 608-621.

Omoto, A. M., and Snyder, M. (1995). Sustained helping without obligation: Motivation, longevity of service, and perceived attitude change. Journal of Personality and Social Psychology 68(4), 671-686.

Pushkar, D., Reis, M., and Morros, M. (2002). Motivation, personality, and well-being in older volunteers. International Journal of Aging and Human Development 55(2), 141-162.

Reeder, G. D., Davison, D. M., Gipson, K. L., and Hesson-McInnis, M. S. (2001). Identifying the motivations of African American volunteers working to prevent HIV/AIDS. Aids Education and Prevention 13(4), 343-354.

Switzer, C. L., Switzer, G. E., Stukas, A. A., and Baker, C. E. (1999). Medical student motivations to volunteer: Gender differences and comparisons to other volunteers. Journal of Prevention and Intervention in the Community 18(1-2), 53-64.

Wilson, J. (2000). Volunteering. Annual Review of Sociology 26, 215-240.

Yeung, A. B. (2004). The octagon model of volunteer motivation: Results of a phenomenological analysis. Voluntas 15(1), 21-46.

Zweigenhaft, R. L., Armstrong, J., Quintis, F., and Riddick, A. (1996). The motivation and effectiveness of hospital volunteers. Journal of Social Psychology 136(1), 25-34. 